\title{
Existence verbs in the Yakut language as evidence of linguistic contacts
}

\author{
Nataliya Sivtseva * \\ North-Eastern Federal University, 677013, Kulakovsky st., apt. 42, Yakutsk, Russia \\ Institute for Humanitarian Research and Problems of Indigenous Peoples of the North, Siberian Branch of the Russian Academy of \\ Sciences, 677027, Petrovsky st., apt. 1, Yakutsk, Russia
}

\begin{abstract}
The article considers the verbs of being in the Yakut language as evidence of language contacts. The purpose of this article is to present the verbs of being in the Yakut language in the light of a comparative study of the verbs of being in related Turkic languages, which is important in solving the problem of defining the historical linguistic community. The novelty is their consideration in the aspect of the problem of linguistic contacts. Their presentation in the Yakut language is relevant in accordance with the principles and methods of linguistic analysis, comparative-comparative study of verbs of related Turkic languages. An overview of the state of study of the verbal lexicon of being in linguistics is presented. It has been determined that the presentation of the characteristics of the lexical-semantic groups of verbs as one of the fundamental components of the functional-semantic field of being in the Yakut language is important in the further presentation of the initial theoretical provisions, determining the fundamental conceptual and methodological principles and substantiating the conceptual and terminological basis for studying the verbs of being in the Yakut language and Turkology in general. It is indicated that the study of the verbs of being in the aspect of the problem of linguistic contacts is important in identifying the corpus of existential verbal lexemes in the Yakut language, determining the lexical-semantic group of verbs of being that are part of the functional-semantic field of the same name, studying the text-forming function of verbs of being in the Turkic languages. It was revealed that such studies are important in establishing a common Pra-Türkic language at the level of the system of lexicalsemantic groups of existential verbs, as well as general and specific in the functioning of existential verbs in the Yakut language and the Turkic languages of Southern Siberia.
\end{abstract}

\section{Introduction}

The category of beingness is a fundamental category in epistemology, dialectics, logic and philosophy; it is also of interest for philological research. The universality of this category is due to its extra-linguistic reality [1]. Being is perceived on the basis of linguistic material, since the idea of it is expressed with the help of the linguistic system. In this regard, the category of beingness is understood as a linguistic category. The verbs of being are the main means of the functionalsemantic field of beingness, they denote the process of being, existence, and presence. Since they represent a fundamental category at the vocabulary level, they require special study. The relevance of the study is also due to its novelty. For the first time, the verbs of being in the Yakut language are considered in the aspect of the problem of linguistic contacts. New is the presentation of the verbs of being in the Yakut language in accordance with the principles and methods of linguistic analysis, comparative study of verbs of related Turkic languages.

\section{Materials and methods}

The purpose of this article is to present the verbs of being in the Yakut language in the light of a comparative study of the verbs of being in related Turkic languages, which is important in solving the problem of defining the historical linguistic community. To achieve this goal, it is necessary to turn to the history of the study of the problem of being verbs in linguistics, to describe the characteristics of the lexical-semantic group of verbs of being as one of the fundamental components of the functional-semantic field of being in the Yakut language, and also to analyze the linguistic material based on the verbal existential vocabulary of Turkic languages of Southern Siberia as related ones. A study of this nature can be helpful in further presenting the initial theoretical provisions, determining the fundamental conceptual and methodological principles and substantiating the conceptual and terminological basis for studying the verbs of being in the Yakut language. Consideration of the verbs of being in the aspect of the problem of language contacts can be important in identifying the corpus of existential verbal lexemes in the Yakut language, determining the lexical-

\footnotetext{
Corresponding author: sivna@mail.ru
} 
semantic group of verbs of being that are part of the functional-semantic field of the same name, studying the text-forming function of verbs of being in Turkic languages.

In this article, the verbs of being in the Yakut language, which represent one of the foundations of the system of the functional-semantic category of being, are the object of special study. The theoretical basis is formed by the provisions set forth in research on functional grammar, vocabulary, grammar, in the Yakut language. The research used the following methods: the method of continuous sampling, used in the collection of research material from lexicographic sources; functional-semantic method, which was used to establish and systematize the forms of expression of the meanings of existence in phases using observation and generalization techniques. The material of the research is existential verbal lexemes with existential meaning, selected by means of a continuous sample from the dictionaries of the Turkic languages. The theoretical and practical significance of the research lies in the use of the results of the work in courses on the functional grammar of the Yakut language, on the basics of stylistics and culture of speech, in lexicographic work, in the further development of the theoretical foundations of the Yakut text.

\section{Results and discussion}

Study of the verbs of being in linguistics. In foreign linguistics, the methods of linguistic manifestation of being are carried out with the study of verbs and syntactic constructions with the meaning of being (E. Benveniste, O. Espersen, C. Kahn, C. Fillmore, E. Clark, etc.). The studies of domestic linguists, starting from the end of the 19th century, present provisions on existential verbs and links, on the existential meaning of some constructions of the Russian language (K.S. Aksakov, A.A. Potebnya), representation of the category of beingness in syntax (A.M. Peshkovsky, A. Shakhmatov).

In linguistics from the second half of the twentieth century, in the study of the category of beingness, various approaches have been outlined. According to the theory of functional grammar the theory of functional grammar (A.V.Bondarko, M.D. Voeikova, E.A.Referovskaya), beingness is understood as a semantic category that contains various options for the meaning of being, existence, presence. The language means expressing these options and related to different levels of the language system are the functionalsemantic field of beingness. In studies representing a linguopragmatic approach to the study of language, beingness is considered as a category that is expressed in a limited part of the syntactic structures of the Russian language (N.D. Arutyunova, E.N. Shiryaev). In contrast to this theory, the syntactic approach to the category of beingness presents it as a category expressing subject-predicate relations as a sign of a separate sentence in Russian (V.V. Vostokov, I.V. Tikhonova). When approaching the category of beingness from the standpoint of the syntax of the text, the functions of sentences with the semantics of being are studied. In the syntax of the text, the category of beingness is manifested in the form of a text-forming factor, which determines the semantic types of fragments of the text and the semantics of the entire text as a whole (I.V. Tikhonova).

The study of the verbs of being, one way or another, is associated with the traditional problems of the study of verbs. The verbs of being are of interest to researchers in the light of the problem of differentiating polysemy and homonymy of the verb word, where the main criteria are semantic analysis based on the semantic derivation of the semantics of a polysemantic word, as well as component analysis, built on a detailed study of the semantic structure of the word (O.S. Akhmanova, V.M. Zhirmunsky, F.P. Filin, L.A. Novikov and others).

The problem of differentiating polysemy and widemeaning is one of the urgent problems in linguistics, since the questions of establishing the limits of meaning of a wide-meaning word, the difference between polysemy and wide-meaning, determining the features of semantic derivation of wide-meaning words require special study (M.V. Nikitin, I.K. Arkhipov and others).

The problem of the relationship between the meanings of words and their compatibility in relation to the study of the semantic structure of polysemous verbs based on the analysis of their lexical compatibility is based on the study of a certain context in determining the meaning of lexical units. In this regard, it is interesting to study existential verbs in contextual design. According to researchers, the semantic meaning of a word in its implementation is associated with the peculiarities of its functioning in sentences/contexts of a certain type [2].

Studies devoted to the lexico-semantic classification of verbs with widely developed polysemy, since "widely developed polysemy" reflect the generalized nature of semantics and the dependence of meaning on the context, are highly regarded, while they are not synonymous with the concept of "wide-meaning" (A.M. Plotnikova, E. A. Chudinova and others).

Existential verbs have been studied in the aspect of current research in the field of the systemic organization of the verbal lexicon, the lexicographic description of which comes from the need to resolve the issue of the status and structure of the lexical-semantic group (F.P. Filin, E.V. Kuznetsova, L.G. Babenko).

The problem of the relationship between regular polysemy and functional equivalence of verbs also covers the study of existential vocabulary. It is advisable to study the issue of functional equivalence of words at the level of LSG, one of the essential features of which is the phenomenon of regular polysemy. Research in this area is related to the fact that these phenomena, represented by the development of the same secondary meanings in words that are semantically similar in basic meanings, characterize the entire lexical-semantic system of the language (N.A. Borovikova, E.V. Kuznetsova and others). 
Research devoted to the problem of classification of models of regular polysemy of verb vocabulary is relevant. There have appeared works in which the structure of a polysemantic verb was studied in relation to certain groups of verbs in the lexical-semantic group (E.V. Kuznetsova, L.M. Vasiliev, A.P. Chudinov and others).

Existential verbal lexicon was studied in the aspect of LSG problems (G.I. Kondratenko, A.P. Chudinov), concept theory (O. M.N. Zametalina, L.I. Lukht, O.V. Senyukova, Yu.A. Klimova, I.V. Tikhonova), dialectal material (M.A. Kazazaeva, A.P. Kargina, N.V. Laguta), syntax (N.D. Arutyunova, E.N. Shiryaev, S.P. Anokhina, N.A. Deryusheva, M.E. Khaitov, V.T. N. Varfolomeeva, M.A. Kazazaeva, A.L. Lenza). Thus, existential verbs were studied in the light of the problems of studying verbal lexicon. Significant results have been achieved in the study of the systemic organization of verb lexicon.

In Turkology, the category of the verb has been sufficiently studied, significant factual linguistic material has been collected. The verb of the Turkic languages is investigated from the position of lexicalsemantic, structural analysis. Semantic groups of verbs (verbs of speech, thinking, action and movement) are distinguished (A.A. Yuldashev, E.V. Sevortyan, P.E. Beloglazov, D.Sh. Batyrmurzaeva). Issues of semantics of individual verbs of the Turkic languages are presented in studies devoted to grammatical categories (E.V. Sevortyan, E.R. Tenishev, A.A. Yuldashev, N.Z. Gadzhieva, A.A. F.A. Ganiev and others).

The problem of comparative lexicology based on the material of various language systems is urgent. Significant results have been achieved in solving the problem of describing lexical-semantic groups of Turkic verbs (E.D. Balygina, N.D. Garipova, D.M. Khasanova, A.N. Chugunekov, M.G. Usmanova, M.D. Chertykova, A.Ya. Salchak and others) and studying lexicalsemantic groups in the Turkic languages (N.Z. Gadzhieva, A.A. Koklyanova, G.K. Kuliev, F.A. M. Khasanova, M. G. Usmanova, M. D. Chertykov, A. R. Tazranova and others). There are studies devoted to the problem of polysemy, methods of interpreting polysemous words (N.Z. Gadzhieva, A.A. Koklyanova, G.K. Kuliev, F.A. G. Usmanova, M.D. Chertykov, A.R. Tazranova and others). In Turkology, the study of existential verbs continues in the light of the study of polysemy issues, the systemic organization of verb lexicon, the presentation of lexical-semantic groups of individual verbs.

The first description of the category of verb in the Yakut language is presented in the work of O.N. Betlingka "On the Yakut language", where a section is devoted to word formation of a verb: a list of indecomposable verb stems is given, distributed into groups depending on the syllable structure, the structure of derived verb stems is considered. This work also presents the first information about the formation of the tense and mood forms of the Yakut verb [3]. To the work of O.N. Betlingka "On the Yakut language" dictionary materials are attached, compiled from printed sources and texts by A.Ya. Uvarovsky (4600 words).
The vocabulary of the Yakut language presented in the dictionary is given in a phonetic notation, provided with a translation, arranged in the alphabetical order adopted in works on Sanskrit, compared by origin with other Turkic and Mongolian languages, its use in a sentence is illustrated. The dictionary contains verbs that refer to the process of being. The work of O.N. Betlingka "On the Yakut language" in the scientific world was highly appreciated as an outstanding event in the comparative historical study of the Turkic languages, "it constituted an era in the study of Turkic languages in Russia and in world science, and was immediately used as a theoretical study in general linguistics. and as a textbook on the Yakut language" [4].

Based on the work of O.N. Betlingka "On the Yakut language" later, grammars of the Yakut language were created, where separate sections are devoted to the verb. In them, some existential verbs are given as examples to the main theses on the verbal system of the Yakut language (S.V. Yastremsky, N.N. Poppe, N.S. Grigoriev, L.N. Kharitonov).

In 1954, the scientific work of L.N. Kharitonov "Types of the verb base" was published, the appearance of which marked new fundamental principles in the development of the category of the verb in the Turkic languages. For the first time, it presented an analysis of the semantic, structural and phonetic-morphological features of various types of verbal stems of the Yakut language, while existential verbs were presented in the composition of state-verbs [5].

Works on the grammar of the Yakut language appeared, in which certain aspects of the verb category were analyzed (E.I.Korkina, G.G. Filippov, N.I. Popova). The results of research on the grammar of the Yakut language were used in the compilation of the fundamental "Grammar of the modern Yakut literary language" in two parts $[6,7]$. They also summarized the conclusions on the study of the verb system in the Yakut language.

Existential verbs in one aspect or another are presented in the works on the lexicology of the Yakut language (P.S. Afanasyev, N.N. Vasilyeva and others). For example, in the monograph by N.N. Vasilyeva, verbal synonymy is presented within the semantic groups, in which the synonymization of groups most often occurs [8]. Existenctial verbs are indicated in the group of verbs synonymy denoting objectless actionsmanifestations and general states: $ө л$ 'die' / быһ / танаралаa 'give your soul to God' / бар 'go (to the other world)'; бүm 'die' / морбой 'stretch legs' / capaa 'die'; cүm 'to be lost, to disappear' / мэлий 'to be lost'; бүm 'to end, to expire' / баран 'to dry out, to end, to be used up' / мэлий 'to end, to deplete; төрөө 'to be born' / Үөскээ 'to be born, to happen' / айыльын 'to be created'; бүm 'stop' / mохтоо 'stop, stop' / уурай 'stop, end'; кырый 'getting old' / сорсуй 'getting old'. Some existential verbs are classified in the following groups:

- synonymy of verbs denoting physical processes: уол 'decrease, dry out, dry up, evaporate' / уоһун 'decrease in volume, decrease, subside';

synonymy of verbs denoting a change in quantitative signs: элбээ 'multiply, increase' / Үксээ ' 
multiply, multiply, increase in number' / дэлэй 'increase' / ханаa 'increase in number, multiply' / мэнээхтээ 'multiply, breed (in large numbers)';

- synonymy of verbs denoting a change in specific (sensory) signs and qualities: a5blp 'to bitter' / axmbıй 'slightly rancid (about oil, fat)'; cblmblǔ 'to rot, to deteriorate' / ыммый 'to rot' / буорту буол 'to deteriorate' / cbimmbiü 'to start to rot, to deteriorate". The analysis of this material by semantic groups allowed the author of this monograph to draw a conclusion about a high degree of synonymous possibilities of verbs.

In our work, it is appropriate to present the lexicalsemantic group of verbs of being as one of the fundamental components of the functional-semantic field of being in the Yakut language. The systematization of the verbs of being in the Yakut language was carried out on the basis of the classification of Russian verbs [9]. The verbal vocabulary of being in the Yakut language can be divided into three large lexico-semantic groups:

1.verbs denoting the initial phase of being, existence (сақалаа 'to begin', төрөө 'to give birth, to be born', Уөскээ 'to be born, to come from something, to happen, to be from somewhere, to grow up somewhere');

2. verbs of existence (баар 'to be, to exist', буол 'to be, to appear, to be done, to become; to be, to occur', олор 'жить, to live');

3. verbs denoting the disappearance, the cessation of being (мөлтөө 'weaken, fade', aхсаа 'weaken', өл 'die, end, perish; fade').

The selection of a lexical-semantic group within the class of existential verbs is based on the designation of phases in the process of being. The verbs within the existential class are distributed in accordance with the semantics of the meaning passed to them. In linguistic literature, phasicity is defined as "the meaning of the beginning, continuation and end of some process or action" [10].

No less interesting is the consideration of the verbs of being in the Yakut language in the aspect of the problem of defining the common Proto-Turkic language. A comparative study of the lexical-semantic groups of existential verbs of related Turkic languages can be a significant help in solving the problem of defining the historical linguistic community, which manifests itself in the proximity of the objects of study, both in structural and semantic terms $[11,12,13]$. In the Yakut language, the lexical-semantic groups of existential verbs did not become an object of comparative study. Such a study can make a significant contribution to the establishment of a common ProtoTurkic language at the level of the system of lexicalsemantic groups of existential verbs. In this regard, it is advisable to consider the existential verbs presented in the monuments of ancient Turkic writing in comparison with the verbs in the Yakut language used in the context of existential use. Let us take a look at some examples. In the Yakut language, the verb of being олор, denoting the process of existence, has the following meanings: ' 2 . live, reside, settle somewhere; 2. inhabit any locality' [14]. This verb in the indicated meanings is set forth in the small and large inscriptions of the Kul-Tegin stele, one of the monuments of ancient Turkic writing: ancient Turk. түрк билгэ хақан бу өдкэ олуртылм / Yakut түҮрк билгэ хаБаана бу кэмнэ олордум 'At that time I lived, the wise kagan of the Turks'; ancient Turk. ха5ан олуртым / Yakut хақан буолан олордум 'lived as a kagan'; ancient Turk. Бумын хаБан, Истэми хаБан олорбуттар / Yakut Бумын хаБан, Истэми хаБан олорбутmар 'Бумын каган, Истэми каган lived' [15].

Revealing the general and specific in the functioning of existential verbs in the Yakut language and the Turkic languages of Southern Siberia is of particular interest, since the Altai, Tuvinian and Khakass languages are genetically closest to the Yakut language $[16,17,18,19,20]$. Consider an example based on the verb being. In the Yakut language, the verb mөрөө, denoting the initial phase of being, existence, has the following meanings: ' 1 . to give birth to a baby, a cub, to give life to a cub, a baby; 2 . to be born as a result of childbirth, to be born (about a person, an animal); 3 . to appear, arise, be born (about something new); 4. to appear, to be observed again in the sky after the disappearance (about the new moon) [21]. The specified verb has similar meanings in the Tuvan language: Tuv.

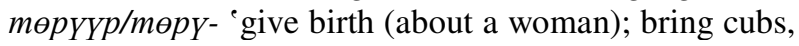
give offspring (about animals); lay eggs (about a bird); be born' [22]. It was revealed that in the modern Tuvan language the form of the verb in question төрүикен is used in relation to animals and is used in the meaning of 'to calf, foal, lamb, farrow', when, as Tsagan-Nur Tuvinians actively use the form of this verb mөручр 'give birth' in relation to a woman [23]. In the Altai language, the verbs төрө- and төрөөр are used in relation to both a person and an animal: Altai mepe'give birth (about animals); mөрөөp 'to give birth; to calve, to lamb' [24]. The following forms of this verb are found in the Khakass language: төри-/mөре/mopupze in the meaning 'to be born' [25]. This verb in all these languages is a verb of being, denoting the beginning of the process of being, existence, has a common Turkic basis depe- with the meaning (after) to be born, give birth' [26].

\section{Conclusion}

Thus, despite the fact that the verbs of being in linguistics are sufficiently studied, their consideration in the aspect of the problem of linguistic contacts is new, their presentation in the Yakut language is relevant in accordance with the principles and methods of linguistic analysis, comparative study of verbs of related Turkic languages. The description of the characteristics of the lexical-semantic groups of verbs as one of the fundamental components of the functional-semantic field of being in the Yakut language, the analysis of the linguistic material based on the verbal existential vocabulary of the Turkic languages of Southern Siberia as related, is important in the further presentation of the initial theoretical provisions, defining the fundamental conceptual and methodological principles and substantiating the conceptual and terminological basis 
for studying the verbs of being in the Yakut language and Turkology in general. The study of the verbs of being in the aspect of the problem of linguistic contacts is important in identifying the corpus of existential verbal lexemes in the Yakut language, determining the lexical-semantic group of verbs of being that are part of the functional-semantic field of the same name, studying the text-forming function of verbs of being in Turkic languages, establishing a common Proto-Turkic language in the level of the system of lexical-semantic groups of existential verbs, as well as general and specific in the functioning of existential verbs in the Yakut language and the Turkic languages of Southern Siberia.

\section{References}

1. M.N. Zametalina, Functional-semantic field of beingness in the modern Russian literary language: Abstract of Ph.D. thesis: (Volgograd, 1995)

2. V.G. Gak, On the problem of epistemological aspects of the semantics of the word, Questions of the description of the lexico-semantic system of the language. Abstracts of reports. (Moscow: MGPI, 1971).

3. O.N. Betlingk Dictionary. About the Yakut language. p. 422-645. (Novosibirsk: Nauka SO, 1990).

4. E.I. Ubryatova, Editor's Foreword. About the Yakut language. (Novosibirsk: Nauka SO, 1990).

5. L.N. Kharitonov, Types of the verb stem in the Yakut language. (Moscow, Leningrad: publishing house of the Academy of Sciences of the USSR, 1954).

6. Grammar of the modern Yakut literary language. Phonetics and morphology. (Moscow: Nauka, 1982).

7. Grammar of the modern Yakut literary language. Syntax._Novosibirsk: Nauka, 1995).

8. N.N. Vasilyeva, Lexical synonyms in the Sakha language. (Yakutsk: State Unitary Enterprise "Polygraphist", 1996).

9. Kuznetsova S.A. (ed), The Big Explanatory Dictionary of the Russian Language (Saint Petersburg: Norint, 2003).

10. N.V. Deeva, Functional and semantic aspect of the verbs of being, $\mathrm{PhD}$ Thesis (Arkhangelsk, 2003).

11. A.V. Bayyr-ool, Particles of the Tuvan language formed from existential verbs in comparison with the Yakut and Khakass languages) $\mathrm{PhD}$ Thesis. (Novosibirsk, 2009).

12. A.R. Tazranova, Functions of existential verbs with verbs of movement in the Altai language, Languages of the indigenous peoples of Siberia p. 145-155. (Novosibirsk, 2002).

13. O.A. Tinnikova, Existence verbs of the Khakass language, Philology and man, 2, 167-173, (2011)
14. P.A. Sleptsov (ed), Big explanatory dictionary of the Yakut language: in 15 volumes. 7, 264-265. (Novosibirsk: Nauka, 2010).

15. N.K. Antonov Ancient Turkic language (VI-VIII centuries). (Yakutsk: books publishing house, 1970).

16. N.R. Oynotkinova, Demonym "aza" in the language and folklore of the Turks of Southern Siberia, Siberian Journal of Philology, 2, 40-52. (2018) DOI: 10.17223/18137083/63/4

17. N.N. Shirobokova Language contacts in the history of the Yakut language Siberian Journal of Philology, 4, 122-128 (2018). DOI: 10.17223/18137083/65/11

18. E.V. Tyuntesheva Lexical-semantic correspondences of verbs of the Altai language in the Turkic languages of Southern Siberia and Kypchak languages (on the example of several lexical-semantic groups), Siberian Journal of Philology. 4, 145-156. (2018). DOI: $10.17223 / 18137083 / 65 / 14$

19. E.V. Tyuntesheva, O. Yu. Shagdurova Semantic variation of interlingual verbal correspondences in the Turkic languages of Siberia and the Kypchak languages, Siberian Journal of Philology, 2, 196-209. (2020) DOI: $10.17223 / 18137083 / 71 / 16$

20. I.V. Shentsova Cultural interaction of ethnic groups according to the Turkic languages of Siberia. Lexical-semantic group "Musical Instruments", Siberian Journal of Philology. 3, 180-191, (2020). DOI: $10.17223 / 18137083 / 72 / 14$

21. P.A. Sleptsov (ed) Big explanatory dictionary of the Yakut language: in 15 volumes, 10, 556-557. (Novosibirsk: Nauka, 2013).

22. E.R. Tenisheva (ed). Tuvan-Russian Dictionary (M.: Soviet encyclopedia, 1968)

23. P. Seren Rites and customs of the Tsagan-Nur Tuvans in Mongolia: materials of language, culture. (Kyzyl: Tyvapoligraf, 2013).

24. O. N. Balakina, V. S. Dedeeva Altai-Russian Dictionary (Gorno-Altaysk: ROO "Lepta", 2015).

25. N. A.Baskakov, A. I. Inkizhekova-Grekul Khakass-Russian Dictionary (Moscow: State Publishing House of Foreign and National Dictionaries, 1953).

26. E. V. Sevortyan Etymological dictionary of Turkic languages: common Turkic and interTurkic bases for the letters " $v$ ", " $g$ ", " $d "$ ", " $m$ ". (Moscow: Nauka, 1980). 